\title{
Exploring the Marketing Effect of Corporate Social Responsibility - An Experimental Design Approach
}

\author{
Quey-Jen Yeh \\ Department of Business Administration, National Cheng-Kung University, Taiwan
}

Copyright $\subset 2017$ by authors, all rights reserved. Authors agree that this article remains permanently open access under the terms of the Creative Commons Attribution License 4.0 International License

\begin{abstract}
Corporate social responsibility (CSR) is value oriented, based on the perspectives of stakeholders and issues considered essential. Using experimental design, this study designs scenarios in terms of consumer's prior purchase experience with products associated to CSRs. The purpose aims to demonstrate the marketing effect of CSR initiative whereby it stimulates buyers to purchase a high priced CSR-related product or stay with such a product when they are aware of the CSR behavior of the seller. Such effect is examined further for those of less or no prior experience in purchasing CSR-related goods. Our goal is to explore the response of general consumers on ethics relevant issues for better understanding of CSR in business.
\end{abstract}

Keywords Corporate Social Responsibility (CSR), CSR Initiative, CSR Awareness, Experiment Design, Experience Goods

\section{Introduction}

The growing awareness of negative and side effects of business activities has drawn public attention on business social contributions (E.g.: [1]). To operate, companies of all size inevitably extracts and utilizes resources from the society and community. The resources include human capital, natural resources, tangible resources such as machinery and property, as well as intangible resources such as brand image and knowledge. Corporate Social Responsibility (CSR) refers to the firm's obligations and legitimate requirements to use its resources in ways to benefit societies (E.g.: [1-3]), required to be built upon a set of guiding ethical principles that can influence strongly organization decision-making process [4]. "CSR" thus is a broad concept wherein companies go beyond their economic and legal responsibilities in the management of business, to take responsibility for their impact on the society by minimizing negative effects and maximizing positive impacts possible to the society as a whole.

For being CSR conscientiousness, businesses are urged to response to not just their shareholders, but a broader set of stakeholders, including customers and local communities [5]. As one primary stakeholder, consumer-based responses to CSR initiatives are prudent to provide corporations with guidance. Positive correlation between CSR and consumer patronage has been evidenced [6]. Because of support of CSR initiatives, consumers prefer to choose products of similar price and quality from socially responsible companies [7]. Studies even show that buyers are willing to pay higher prices for products of similar quality that are perceived ethical and socially responsible [5, 8-11]. This is especially evident in experience goods - products whose quality cannot be evaluated or determined by inspection prior to purchase. For instance, Carvalho et al. [12] prove the presence of purchase intention when the CSR associated food product is priced $10 \%$ higher. They further show that price fairness plays a significant mediator between CSR perception and purchase intention. It appears that CSR initiative to consumers is not simply a symbol of ethics, but an economic one. Businesses should integrate social concerns in their operations and in interaction with the stakeholders on a voluntary basis.

Information asymmetry grants firms better knowledge about the quality of their products than buyers have [13]. To reduce risk and avoid being cheated, consumers look for extrinsic cues of unobservable product quality [14]. They are convinced to purchase goods based on sellers' quality cues, such as advertising [15], price [16], brand, reputation [17], warranties [13], and CSR actions [18,19]. Review of these studies echoes that consumers who lack the ability to determine a product's value before purchasing are more likely to associate CSR as a positive signal indicating the firm's honesty and reliability [20,21]. This is especially evident in experience products, products' whose quality cannot be evaluated or determined by inspection prior purchase. Firms selling experience products are indeed more likely to gain consumers' product favor and purchase support through positive CSR activities [22]. This positivity of CSR initiatives in relation to experience goods raises the question: What if consumers have previously purchase experience such that the quality of the product is known, 
and that CSR is no longer a cue to undergo the product quality, will the same level of CSR effect remain? Little CSR research has been done to determine the value of CSR in contrast to CSR signaling and personal prior purchase experience.

People exhibit patterns of decision making in relation to information framing in that different frames may change completely people's mindset for decision choices even though the information context remains similar. To answer the question, this study draws on CSR significance supplementary with signaling theory for experience goods. The research procedure involves experimental design in terms of consumer's prior purchase experience with production firms associated to CSRs. The purpose aims to demonstrate the effect of CSR initiative whereby it stimulates consumers to purchase a high priced CSR-related product, and that this effect can extend to consumers of less or no prior experience of purchasing CSR-related goods. Milk was chosen as an example of experience goods for several reasons. Firstly, CSR in the food industry is particularly important due to the various potential benefits, with food safety becoming the ultimate CSR concern [23]. With China's milk scandal in 2008, products of 22 brands, exceeding $90 \%$ of liquid milk and $50 \%$ in powdered milk of total market share was confirmed to be contaminated with melamine [24], consumers are now more cautious when purchasing milk. In addition, milk is commonly consumed product, purchased by consumers of all age as it is relatively affordable, this allows less limitation in the sampling process to obtain a general picture of all consumers. We first evidence that consumers are more likely to purchase and stay with a higher priced CSR-related product, and further, they would not switch to a lower priced one without CSR attempt. We then show that prior purchase experience moderates this relationship. Boundary of the price extent is also examined. The findings add to the CSR literature in that CSR is not simply a symbol of ethics, but also an economic niche to provide businesses with guidance.

\section{Review of Literature}

\subsection{Corporate Social Responsibility (CSR) and Relevance}

Corporate social responsibility (CSR) has been claimed synonymous with varying concepts, including human rights, fair and equal treatment of employees, equal right between sex and between religious groups, as well as protection of the environment and support of community (e.g.: [18]). More than $90 \%$ of the Fortune 500 companies have shown explicit social initiatives $[25,26]$. Consumers appear tending to favor towards brands that are tied and associated to a social cause as compared to those that aren't [27]. With association to causes, the actions seemly enable the visibility and respect of the firms to portray them a social responsible mindedness and even patriotism image [28]. As a sub-stream of CSR, the use of corporate philanthropy and cause-related marketing is increasing worldwide, benefiting both firms and causes [29], making managers and marketers aware of CSR benefits in brand building, better firm reputation, and improved sales [30]. Corporate social behavior appears to be an effective practice in marketing products, services, brand, and the company.

Regardless CSR as a firm's obligation to use its resources in ways to benefit society as a whole, its broad definition makes it difficulty in measurement. Earlier, Freeman [31] from business ethic perspective specifies varied elements, of which the measuring instrument must be value-based and include the relevant stakeholders of the organization to deal with the issues it regards as salient. Sen and Bhattacharya [32] based on a search of 600 firms' actions suggest six categories of business social liability: product (e.g., product safety, product-harm disputes), environment (e.g., environment friendly products, waste management), diversity (e.g., sex, race, disability- based initiatives), non-domestic operations (e.g., overseas labor and practices), workforce (e.g., employee job security, safety concern), and support of community (e.g., support of health programs and educational activities). Hartlieb and Jones [2] assess the contribution of UK ethics and social and environmental labeling schemes to sustainable consumption and production, through a qualitative survey of fifteen UK initiatives regarding social justice, food processing, animal welfare, environmental sustainability and others. Castaldo et al., [12] instead suggest investigate the link between consumers' perception about whether a firm is socially oriented and their purchase intention of buying products from that firm.

Recently, most scholars suggest that an application of CSR should be oriented at two conditions: (1) The products sold need to comply with social requirements or ethical standards; (2) The firm has an acknowledged commitment to protect consumer rights and interests, or equivalently prior CSR reputation (E.g.: [1-3]). In use of experimental scenarios, product-harm researches study the benefit of CSR on reduction of consumers' emotional anger [33], adjustment of consumers' attributions [20], regain of a firm's good reputation [34], and sustainment of consumer trust and purchase intention [35]. In view of this, a CSR experiment appears required to encompass the three ingredients, value-base, relevant stakeholders, and CSR issues, analogous to the psychological value function and neutral reference concept [31]. Accordingly, the current experiment scenario comprises three paradigms: (1) triggers (e.g., disclosure of publicity); (2) organization background (e.g., SR reputation or firm response); (3) influence (e.g., consumer response or purchase intention).

\subsection{The Current Research: CSR as a Marketing Approach in the Food Industry}

Due to the wide range of benefits, food safety has being the ultimate social concern, and CSR is particularly important in the food industry [23]. Food retailers and 
producers are driven to apply methods to communicate with CSR and report their commitment [36]. The UK's large food retailers are increasingly keen to report their commitment to CSR, integrating it as an element of their core business [37]. Messages such as fair trade, fitness, healthy living, healthy eating, organic production, sustainability, employment policies, charitable giving, and support for local communities have all been used by food producers. The increasing tendency to publish CSR reports can explain the high expectations [33]. In turn, three types of generalized CSR ingredients are categorized in food businesses: product responsibility that concerns producing healthy and environmentally-friendly products; human responsibility that concerns products by means of good animal farming and positive work conditions; environmental responsibility that cares for product defects and quality, content declaration, and live-up expectations [18]. Apparently, CSR initiatives have been integrated as a core business element in the food industry [37]. In addition, due to the 2008 milk melamine contamination crisis outbreak, most serious CSR crisis in China, consumers tend to be more cautious when buying such consuming products. Thus, viewing CSR initiatives as the trigger and milk product as the target, we first assume,

H1: Buyers have higher intention to purchase a CSR-related product even if its price is higher than a similar one which is non-CSR-related.

Despite the advantage, use of CSR as a marketing tool in the food industry should be dealt with care, because excess manipulation may cause negative effects. Seigel and Vitaliano [21] found that firm's level of enthusiasm about CSR depends on consumer's purchase intention in relation to CSRs. They further indicate that this initiative varies and correlates with product category. Based on Nelson's [38] definition, products can be classified in three categories: search, experience and credence. Search products are those whose attributes and quality can be evaluated by inspection or research prior purchase, whereas the quality of experience products cannot be. The value of credence products cannot be determined even after use. Indeed, firms of experience products are more likely to engage in CSR marketing because experience goods must be consumed or used to determine the true value [38].

Practices of CSR in all industries allows firms to build a reliable and honest reputation that may act as a quality signal when consumers purchase experience products $[20,21]$. As previously mentioned, it is evident that consumers are not only willing to purchase CSR-related products, but are often willing to pay higher prices for products from companies when they are aware of [8-11]. This awareness may be due to their association of CSR initiatives to firm reliability and product quality. We thus further assume that customers' CSR awareness would affect positively on their purchase intention of a higher priced CSR-related product:

H2: Buyers' awareness of a firm's CSR actions is positively related to their intention of buying a higher priced CSR-related product from the firm.

The positive linkage between CSR and customer patronage has allowed managers to realize that in today's marketplace CSR is not only an ethical imperative today, but also an economic one [6]. Particularly, consumers tend to associate experience goods with CSR, using CSR support as a signal for product honesty and reliability of a firm. They in turn would be more loyal to a CSR product when they acknowledge that it is CSR-related compared to one which is not. Thus,

H3: Buyers are more willing to stay with a CSR-related product even if its price is higher, when this product is their frequently-buy than one which is not.

Further, due to the fact that consumers may acknowledge the quality and value of the product and thus less need to rely on CSR as a signal, the marketing effect of CSR appears related to consumers' purchase experience. Namely, the effect could be weaker when they acknowledge the quality and value of the product due to prior use experience, and thus need less CSR as a signal, while the effect is stronger when they have no prior experience. Thus, we assume that buyers' previous purchase experience moderates the relationship between CSR awareness and purchase intention hypothesized in $\mathrm{H} 3$,

H4: Buyers' purchase experience will moderate the relationship between their purchase intention and CSR awareness of the firm's higher priced CSR product:

The relationship is stronger when their experienced product is CSR-related, otherwise, it is weaker.

\section{The Research Method}

As shown in Figure 1, the research framework comprises the CRS initiatives performed by the firm and how buyers respond to it when they are aware of the firm's CSR actions, and if their prior purchase experience of CSR-related goods moderates the relationship. The response, namely the marketing effect, is measured by purchase intention and choice. Based on the framework, we propose the four hypotheses addressed above.

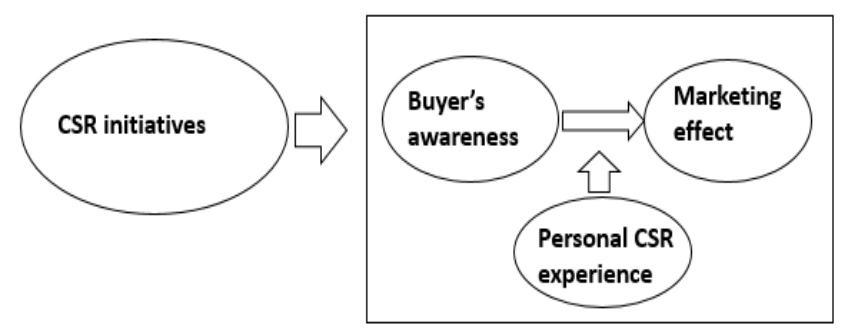

Figure 1. The research framework

\subsection{The Experiment Procedure}

As previously addressed, experimental scenarios approach can apply to explore people's mind set through a manipulation of the external information frame in social issues (e.g., [33, 20, 34, 35]). For the purpose, we utilize this approach. The goal is to testify the hypotheses under an identical CSR exposure with different hypothetical scenarios 
of consumer's CSR product purchase experience. As one most affected social benefit issues [23], food safety has been an important consumer-based CSR issue. In order to associate with familiar, experience goods for the experiment, a frequently consumed and affordable product, milk, is chosen as the subject product.

A questionnaire, each with a storyline and five sets of response measurements, is developed. The story comprises: (1) A poster of a firm's CSR doings; (2) Role play of different personal purchase experience of a milk product related to the CSR poster; (3) Measurements of response, including rating on the preferences between the CSR and the non-CSR brand milk with the former price $10 \%$ higher. Three CSR purchase experience scenarios are designed. Therefore, whilst the questionnaire items are all identical, the storyline differs in the personal CSR-product purchase experience. Personal CSR expectation and demographic information such as sex, age, education level, occupation and monthly disposable income are collected as the covariates in the data analysis to remove the personal effects.

Factor analysis applies to extract factors and assess the discriminant and convergent validity of the measures. Four main indicators are used as the standard criteria of validity analysis in this research: factor loading over 0.6, Eigenvalue over 1 , total explained variation over $60 \%$ and $\mathrm{KMO}$ over 0.6. Internal consistency of Cronbach's Alpha was confirmed using reliability test. Standards such as Item-to-total is over 0.3, and Cronbach's Alpha over 0.7 are the reliability criteria. Analysis of covariance and moderating regression, both treating personal information as the covariates, apply to exam the hypotheses.

We describe the details below according to the order of the storyline, the measurements, and the sample.

\subsection{The Storyline}

Using milk as the target goods, we first create an illustrating poster, as displayed in the APPENDIX, regarding the CSR initiatives of Brand A from company A to begin the story. All respondents are exposed to this same CSR poster of Brand A. The purpose is to portray the strong, positive CSR image of Brand A. At the same time, the respondents are informed that the price of the CSR related Brand A is $10 \%$, in this case NT\$15 (30NT\$: 1US\$), more expensive than the non-CSR Brand B from company B.

We then create three scenarios to examine the impact of personal CSR-product purchase experience: No previous purchase experience as the control group, and previous frequent-buy experience of CSR and non-CSR milk goods. These three types of experience are designed as below.

Scenario 1: No prior purchase experience of CSR products.

Suppose you enter a supermarket to buy milk, only Brand $\mathrm{A}$ and Brand B are available, but you have no experience in purchasing either of them before. There is no difference in volume or appearance, but the price is different: Brand A

\section{NT\$ 174 and Brand B NT\$159.}

Scenario 2: Prior purchase experience of CSR products.

Suppose you always buy Brand A. One day, when you go to the supermarket to buy Brand A, you see the new Brand B. Compared to Brand $\mathrm{A}$, there is no difference in volume or appearance, but yet there is a difference in price: Brand A NT\$ 174 and Brand B NT\$159.

Scenario 3: Previous purchase experience of non-CSR products.

Suppose you always buy Brand B. One day, when you go to the supermarket to buy Brand B, you see the new Brand A. Compared to Brand $\mathrm{B}$, there is no difference in volume or appearance, but yet there is a difference in price: Brand A NT\$ 174 and Brand B NT\$159.

\subsection{The Measurements}

Manipulation check: In order to ensure the design validity, two manipulation checks apply to eliminate respondents who do not fully understand the story. The first question, "Which brand of milk do you usually purchase according to the story given," examines if respondents read the personal CSR experience scenarios right. The answer should be simply Brand A, Brand B, or neither depending on which scenario given. The second question asks respondents if they understand the content of Brand A's CSR poster. The answer is ranged on a 5-point scale ( $1=$ Totally don't understand; $5=$ Totally understand). Respondents who (1) misunderstood the given personal CSR experience scenario, or (2) rated totally don't understand the content of Brand A's CSR poster, are removed from further analysis.

Consumer's expectation of CSR: This scale defines consumers' expectation of CSR, as part of personal CSR-attitude. Four items adopted from Creyer [39] consists the measurement, which include: "Firms have a responsibility not to ever act unethically", "Firms have a responsibility to always act with the highest of ethical standards', "I expect the firms that I deal with to act ethically at all times, and "All firms will be unethically sometimes: it is normal (a reverse statement)". As shown, they aim to measure the extent to which a customer would tolerate the unethical behavior of a firm in general. The choice option uses a seven point Likert scale with 1 representing strongly disagree and 7 strongly agree.

Awareness of the CSR poster: This scale defines the extent to which a customer is aware of a firm in performing CSR initiatives. Commission of the European Communities [40] define CSR as "A concept whereby companies integrate social and environmental concerns in their business operations and in their interaction with their stakeholders on a voluntary basis". Accordingly, for the current experimental purpose, we design this measurement as the extent to which a customer is aware of the Brand A's CSR activities he or she is exposed to as given in the poster of Figure 1. Four items are designed, which ask respondents if Brand A: "Demonstrates that it is concerned with the environment", 
"Is involved in the community and makes investment in worthwhile causes", "Demonstrates focus on employee benefit and provides excellent work environment", and "Implements good corporate governance and information transparency". The choice option uses a seven point Likert scale with 1 representing strongly disagree and 7 strongly agree with the given Brand A's CSR poster.

Purchase intention: This scale defines the intention to which a customer is more willing to buy between a higher priced CSR goods and a lower priced non-CSR goods, whereby both seemingly have the same quality. Four items consists the measurement, including: "Which brand will make you feel good about yourself?", "Which brand will make you feel that you are doing the right thing?", "Which brand has a higher probability of you purchasing it?", and "Which brand are you more willing to buy?". They are modified from the purchase intention measures of Jamieson and Bass [41] and [5]. The choice option is on a semantic differential seven-point scale item $(7=$ Brand $\mathrm{A} ; 1=$ Brand B). That is, the larger the higher intention to buy Brand A, otherwise, the smaller the higher intention to buy Brand B.

Tolerance of choosing the higher priced CSR product: This scale tends to measure the intention tolerance of consumers in purchasing a higher price CSR product than one which is not. It illustrates two milks, Brand A is from the CSR firm shown in Figure 1 and Brand B which is not, of similar appearance and different prices. The choice option of the price of Brand A is ranged from $\$ 174$ to $\$ 199$, compared to the fixed price of $\$ 159$ for Brand $B$, with each price comparison increased by $\$ 5$ difference. The choice option also uses a semantic differential seven-point scale item ( 7 = Brand A; 1 = Brand $\mathrm{B})$.

\subsection{The Sample}

Since the product, milk, under purchasing consideration in this experimental design, is a commonly consumed product, easily purchased and affordable, the sampling is not restricted. This study targets a wide variety of respondents in terms of age, education level, occupation and income to depict an overall image of consumer response to the marketing effect of CSR. In attempt to investigate a sample of broader demographic characteristics, we approached respondents via paper questionnaires and Internet surveys on Facebook, PTT, as well as in shopping malls during $20^{\text {th }}$ April to $2^{\text {nd }}$ May 2015. Stratified random sampling was applied. That is, each respondent was shown randomly only one of the three scenarios. This way divides the respondents equally into three groups with each group differing in prior buy experience of a CSR goods based on the two choices of different CSR-signaled and priced products. Respondents are randomly given one of the three scenarios to fill out in their own time and presence to ensure confidentiality of response.

Of the 346 questionnaires returned, a total of 35 were invalid and removed from further data analysis because they either (1) misunderstood the purchasing experience that they were supposed to play with given in the three CSR experience scenarios, or (2) they indicated that they totally did not understand the content of Brand A's poster. Eventually, a total of 311 respondents and questionnaires, where $\mathrm{N}=102$ for scenario $1, \mathrm{~N}=99$ for scenario 2, and $\mathrm{N}=110$ for scenario 3 respectively, remain for further data analysis. Table 1 displays the demographic features of this sample. ANOVA tests indicated that there are significant differences in age, education level and monthly disposable income (NT\$), among the three scenarios, which are due to that Scenario 3 has the most younger, lower income graduate students. These significances also suggest the need of controlling the effects of personal demographics in the hypothesis testing.

As Table 1 illustrates, of the total sample profile, the proportions between male and female respondents are fairly even: Although scenario 1 has the most male of $55.9 \%$ and least female of $44.1 \%$, there are no significant gender percentage differences in the three scenarios. The most dominant age category of all respondents is "21-25 years" for all three scenarios, respectively $43.1 \%, 43.4 \%$ and $57.3 \%$ for scenarios 1, 2 and 3. Most respondents have a master's degree $(48.0 \%, 38.4 \%$, and $50.9 \%$ respectively) and are currently a student $(54.9 \%, 48.5 \%$ and $64.5 \%$ respectively) among the three groups. As for monthly disposable income (NT\$), categories "5,001-10,000" and " 10,001 - 20,000" together compose the majority of respondents in the three scenarios: $54.9 \%, 61.6 \%$ and $67.3 \%$ for scenarios 1,2 and 3 respectively, where $32 \mathrm{NT} \$=1 \mathrm{US} \$$. Overall, this sample shows fairly a homogeneous profile among the three scenarios.

\section{The Results}

\subsection{Response Differences among the Three Scenarios}

To determine the responses due to the three different CSR experience scenarios, Analysis of Covariance with personal demographics treated as the controlling variables first applied to test the mean differences among the three scenario groups. As shown, the F-value in the first column of Table 2 is insignificant, while the other two F-values are significant. These insignificant differences in personal CSR expectation, while significant differences in the awareness of Brand A's CSR poster and purchase intention for Brand A among the three group, suggest the subsequent scenario analyses are not correlated to personal CSR expectation, but to the current scenario designs. Specifically, among the three scenarios, scenario 2, the group often purchases Brand A that is related to CSR poster, has a highest awareness of the CSR poster. Further, with an average of all over 4.50 in a 7-point scale across the three groups, the three scenarios all reveal a higher purchase intention for the higher priced CSR-product of Brand A over Brand B, though among which scenario 2 has the highest Brand A purchase intention. Therefore, consisting with our design and hypothesis, the three 
scenarios all have a higher intent to purchase a CSR-related product even if its price is higher than a similar one which is non-CSR-related. In addition, the two significances show that respondents who are assigned to scenario 2 are most likely to choose the higher priced CSR Brand A to buy, while those assigned to scenarios3 are least likely, and scenario1, the control group, is in the middle.

\subsection{Buyer Choice Due to the CSR Experience Scenario}

Table 2 also shows that, among the three scenarios, scenario 2 has a purchase intention score of 5.74 most close to 7 , while scenario 3 has one of 4.50 most far away from 7 . The control group falls on 4.92 between the two. These significant differences allow K-means clustering to separate the sample into groups of buyer choice for either Brand A or B. Where, we separated those with purchase intention scores smaller than the overall mean 5.05 across the three scenarios as more preferring to choose Brand $\mathrm{A}$, and those smaller than it as more preferring to choose Brand $\mathrm{B}$. Table 3 displays the results. As shown, the results in Table 3 indicates a significant higher percentage of Brand A choice than those of Brand B across the three scenarios ( $\mathrm{F}$-value $=4.560)$.

Table 3 further shows: Scenario 2, i.e., CSR experience group, has the highest percentage $(88 \%)$, followed by scenario 1 of control group (81\%), and finally scenario 3 of non-CSR experience $(65 \%)$. In other words, respondents who are assigned to the scenario of frequently buying a CSR-product for role play are most prone to stay with it, even though they realize that its price is higher. These significantly larger percentages of choosing Brand A than Brand B across the three scenarios in Table 3, together with the significantly higher scores of awareness of Brand A's CSR poster and its purchase intention than those of Brand B in Table 2, evidence Hypotheses H1 H3.

\subsection{The Moderating Effect of CSR Experience Scenarios}

Hierarchical regression applies to test the relationship between consumers' awareness of a firm's CSR actions and intention to buy its high priced CSR product, and if this relationship is moderated by their prior CSR-product purchase experience for hypotheses $\mathrm{H} 3$ and $\mathrm{H} 4$. For the moderation, we uses two $(0,1)$ dummy variables to represent respectively the two contingencies of scenario 2 and scenario3. Further, demographics, including sex, age, level of education, occupation, and monthly disposable income, are treated as control variables. The results show that none of them are significant. Table 4 displays the results.

Model-1 in Table 4 reveal a significant positive relationship $(.461 * * *)$ between consumer CSR awareness and purchase intention for Brand A, the CSR one. Model-2 shows that this significance remains $\left(.464^{* * *}\right)$, after the two purchase experience variables D1 and D2 and their moderation insert. Thus, Hypothesis $\mathrm{H} 3$ is supported.

Other than this and the negative significance of D2 for scenario $3\left(-.199^{* * *}\right)$, Model 2 also reveal that the significant moderating effect is due to D1, the CSR purchase experience of scenario $2(.113 *)$. To simplify the comparisons, Figure 2 shows the moderating effects among the three scenarios.

Figure 2 evidences the moderation of buyer's previous CSR-product purchase experience on the marketing effect of a firm's CSR conducts. In which, the effect is weaker (stronger) when the buyers have (do not have) prior purchase experience of the product. The results appear consistent with the experience product feature in that when consumers have experienced a product quality, they would reduce to look for extrinsic cues of unobservable product quality, because the risk of being cheated has been reduced by personal experience. Hypothesis H4 thus is supported.

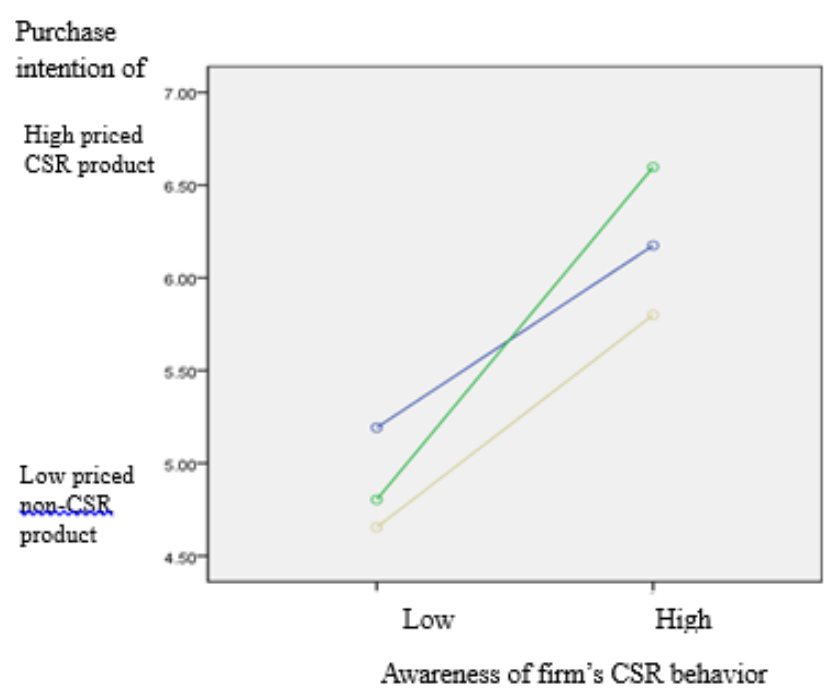

Figure 2. The moderating Diagram

\subsection{Purchase Intention and Price Increase Tolerance}

To test the price gap that consumers would tolerate to buy the CSR milk goods when they initially choose to buy the high priced CSR milk of $\$ 15$ more, $\$ 174$ and $\$ 159$, a gradually increase series of price gap is designed. Table 5 shows these ratings based on a 7-point scale, where 7 implies definitely staying with the CSR Brand A, while 1 indicates definitely not. Therefore, 4 is the medium, and a rating of 5 or above implies intention of staying with Brand A, otherwise it is not.

As shown, it appears that scenario 2 - the group frequently buy CSR Brand A in the role play, has the highest price tolerance, which is up to $\$ 40$. The group of scenario 1 of no particular experience follows, which is up to $\$ 30$, and finally, the group of scenario 3 , which is up to $\$ 25$. As before, scenario 3 - the one frequently buy non-CSR-product in the play, has the least tolerance for the price increment. To this end, we may conclude the influence of role play on player's decision. Overall, those who played to 'frequently buy a cheaper non-CSR product' appear to be more price concerned, while those played to 'frequently buy a CSR product' are more CSR dedicated. 


\section{Conclusions}

In the competitive market today, CSR has become a popular practice. Businesses of all sizes take resources from the society and community where they exist. In return, they require to contribute beyond their obligations required by the law. Taking milk as an example for experiment, this study demonstrates that consumers' awareness of a firm's CSR practices, and their prior personal purchase experience purchase of CSR or non-CSR product, is related to their intention of buying a high priced CSR product from the firm. It appears that CSR can create a positive marketing effect to both the society and the firm. Overall, this study demonstrates the following contribution.

This article makes several contributions to CSR literature. We first evidence that CSR can enhance people's purchase intention of high priced CSR products when they recognize the CSR involvement of the firm, where the price gap can be up to more than twenty percent. We then expose that consumers' prior CSR-product purchase experience, either frequently buy a CSR or non-CSR product, moderates their decision in choosing a product of CSR-related brand. In particular, when they are more used to CSR-product, they appear more likely to stay with such a product even when the price is twenty percent higher. CSR initiatives appear able to communicate customers with quality cue, and motivate them to stay with buying the product.

On the other hand, may be because of having experienced the product quality and thus less need to rely on CSR as a signal, those who are lack of experience in buying a certain CSR goods are weaker in the insisting than those who are used to. Even so, this lacking experience group still appears more likely to choose the CSR-product. In other words, CSR as a cue seemingly is not just able to generate consumers' dependability, but also their connection of a firm's concern in CSR to concern in product quality. This also implies that consumers' tolerance of a higher priced CSR product may vary dependent on their prior CSR-product purchase experience. The tolerant range of those who have prior CSR experience appear to be larger.

Overall, due to its effectively retaining old customers and further attract new ones with no previous purchase experience, we may conclude the positive marketing effects of CSR cues. However, firms must confirm their CSR actions and reputation. Advertisement or allowing consumers to acknowledge the firm's CSR practices next to the products may help to increase the exposure of the firms for their CSR activities. The level of CSR support via purchasing behavior does vary among consumers of different purchase experience: consumers with previous purchase of CSR product are the most supportive, followed by no previous purchase experience, and finally consumers with previous purchase of non-CSR product.

There are some limitations in this research. First of all, although the proposed methodology is adaptable to a wide variety of products, only one relatively cheap commodity was experimented. Hence it is uncertain whether or not the results would be identical for different products. Secondly, this study focuses on CSR advertisement in supermarkets. Other media on the Internet are common today. Future research can determine the effect of CSR initiative on other media to depict a bigger picture. To this end, marketers should acknowledge the signaling effect of CSR.

\section{Acknowledgements}

The author would like to thank Yu-Hsian Hwang for her data collection and proposing of many fantastic ideas, and Dr. Tai-Ping Chang for his constructive suggestions. This author also thanks the Ministry of Science and Technology, Taiwan for its financial support of this research. 
Table 1. Demographic features of the sample across the three scenarios $(\mathrm{N}=311)^{\text {a. c. }}$

\begin{tabular}{|c|c|c|c|c|c|c|c|c|}
\hline \multirow{2}{*}{\multicolumn{2}{|c|}{ Demographics }} & \multicolumn{2}{|c|}{$\begin{array}{l}\text { Scenario } 1 \\
(\mathrm{~N}=102)\end{array}$} & \multicolumn{2}{|c|}{$\begin{array}{c}\text { Scenario } 2 \\
(\mathrm{~N}=99)\end{array}$} & \multicolumn{2}{|c|}{$\begin{array}{l}\text { Scenario } 3 \\
(\mathrm{~N}=110)\end{array}$} & \multirow[t]{2}{*}{ F-value } \\
\hline & & $\mathrm{n}$ & Pct. (\%) & $\mathrm{n}$ & Pct. (\%) & $\mathrm{n}$ & Pct. (\%) & \\
\hline \multirow{2}{*}{ Sex } & Male & 57 & 55.9 & 51 & 51.5 & 52 & 47.3 & \multirow{2}{*}{0.782} \\
\hline & Female & 45 & 44.1 & 48 & 48.5 & 58 & 52.7 & \\
\hline \multirow{6}{*}{ Age } & $<20$ & 9 & 8.8 & 4 & 4.0 & 5 & 4.5 & \multirow{6}{*}{$6.065 * *$} \\
\hline & $21-25$ & 44 & 43.1 & 43 & 43.4 & 62 & 57.3 & \\
\hline & $26-30$ & 15 & 14.7 & 4 & 4.0 & 18 & 16.4 & \\
\hline & $31-35$ & 10 & 9.8 & 9 & 9.1 & 5 & 4.5 & \\
\hline & $36-40$ & 16 & 15.7 & 25 & 25.3 & 12 & 10.9 & \\
\hline & $>40$ & 8 & 7.8 & 14 & 14.1 & 7 & 6.4 & \\
\hline \multirow{3}{*}{$\begin{array}{l}\text { Level of } \\
\text { education }\end{array}$} & High school & 25 & 24.5 & 30 & 30.3 & 18 & 16.4 & \multirow{3}{*}{$3.029 *$} \\
\hline & Bachelor & 28 & 27.5 & 31 & 31.3 & 36 & 32.7 & \\
\hline & Master or above & 49 & 48.0 & 38 & 38.4 & 56 & 50.9 & \\
\hline \multirow{8}{*}{ Occupation } & Student & 56 & 54.9 & 48 & 48.5 & 71 & 64.5 & \multirow{8}{*}{1.067} \\
\hline & Manufacturing & 4 & 3.9 & 11 & 11.1 & 7 & 6.4 & \\
\hline & Business/services & 7 & 6.9 & 10 & 10.1 & 7 & 6.4 & \\
\hline & Government sector & 10 & 9.8 & 8 & 8.1 & 3 & 2.7 & \\
\hline & Retail \& logistics & 9 & 8.8 & 10 & 10.1 & 8 & 7.3 & \\
\hline & Teaching/education & 7 & 6.9 & 7 & 7.1 & 5 & 4.5 & \\
\hline & Finance \& insurance & 4 & 3.9 & 5 & 5.1 & 4 & 3.6 & \\
\hline & Others & 5 & 4.9 & 0 & 0 & 5 & 4.5 & \\
\hline \multirow{6}{*}{$\begin{array}{l}\text { Monthly } \\
\text { disposable } \\
\text { income b. } \\
\text { (NT\$) }\end{array}$} & $<5,000$ & 11 & 10.8 & 6 & 6.1 & 12 & 10.9 & \multirow{6}{*}{$3.810^{*}$} \\
\hline & $5,001-10,000$ & 23 & 22.5 & 28 & 28.3 & 41 & 37.3 & \\
\hline & $10,001-20,000$ & 33 & 32.4 & 33 & 33.3 & 33 & 30.3 & \\
\hline & $20,001-30,000$ & 16 & 15.7 & 8 & 8.1 & 10 & 9.1 & \\
\hline & $30,001-40,000$ & 11 & 10.8 & 11 & 11.1 & 8 & 7.3 & \\
\hline & $>40,000$ & 8 & 7.8 & 13 & 13.1 & 6 & 5.5 & \\
\hline
\end{tabular}

a. ANOVA tests indicated that there were no significant differences in each demographic item among the three scenarios. b.32NT $\$=1$ US $\$$.

c. The data source: [42].

Table 2. Mean differences of the responses among the three scenarios

\begin{tabular}{|c|c|c|c|}
\hline $\begin{array}{l}\text { Variables } \\
\text { Scenarios } \\
\end{array}$ & Expectation of CSR ${ }^{\text {a. }}$ & $\begin{array}{l}\text { Awareness of Brand A } \\
\text { CSR poster }{ }^{\text {a. }}\end{array}$ & $\begin{array}{l}\text { Purchase intention for } \\
\text { Brand } \mathrm{A} \text {. }\end{array}$ \\
\hline $\begin{array}{l}\text { 1. No prior experience } \\
\text { (Control group; } \mathrm{N}=102 \text { ) }\end{array}$ & 6.34 & 5.96 & 4.92 \\
\hline $\begin{array}{l}\text { 2. Brand A purchase experience } \\
\text { (Frequent buy CSR Brand: } \mathrm{N}=99 \text { ) }\end{array}$ & 6.44 & 6.37 & 5.74 \\
\hline $\begin{array}{l}\text { 3. Brand B purchase experience } \\
\text { (Frequent buy non-CSR Brand; } \mathrm{N}=110 \text { ) }\end{array}$ & 6.27 & 6.10 & 4.50 \\
\hline F-values ${ }^{c .}$ & 2.013 & $6.831 * *$ & $12.681 * * *$ \\
\hline
\end{tabular}

a. 7-point Likert scale: 1 strongly disagree; 7 strongly agree.

b. Semantic differential 7-point scale for purchase intention: 7= Absolutely intend for Brand A; 4= no difference; $1=$ Absolutely intend for Brand B.

c. Significance: $* * \mathrm{p}<.01 ; * * \mathrm{p}<.001$ 
Exploring the Marketing Effect of Corporate Social Responsibility - An Experimental Design Approach

Table 3. Choosing percentages between the two brands across the three scenarios

\begin{tabular}{|c|c|c|c|}
\hline $\begin{array}{c}\text { Variables } \\
\text { Scenarios }\end{array}$ & $\begin{array}{c}\text { Percentage of } \\
\text { Choosing Brand A }\end{array}$ & $\begin{array}{c}\text { Percentage of } \\
\text { Choosing Brand B }\end{array}$ & $\begin{array}{c}t \text {-test between the two }{ }^{\text {a. }} \\
\text { brands for each scenario }^{\text {1. No prior experience }}\end{array}$ \\
\hline $\begin{array}{c}\text { (Control group; N=102) } \\
\text { 2. Brand A purchase experience } \\
\text { (Frequent buy CSR Brand; N=99) }\end{array}$ & $81 \%$ & $19 \%$ & $15.333^{* * *}$ \\
\hline $\begin{array}{c}\text { 3. Brand B purchase experience } \\
\text { (Frequent buy non-CSR Brand; N=110) }\end{array}$ & $88 \%$ & $12 \%$ & $16.727^{* * *}$ \\
\hline F-value among the three scenarios & $65 \%$ & $35 \%$ & $17.985^{* * *}$ \\
\hline
\end{tabular}

a. Significance: ${ }^{*} \mathrm{p}<0.05 ; * * * \mathrm{p}<.001$

Table 4. Results of moderating regression analysis $(n=311)$ a.

\begin{tabular}{|c|c|c|}
\hline \multirow{2}{*}{} & \multicolumn{2}{|c|}{ Purchase intention of Brand A } \\
\cline { 2 - 3 } & Model 1 & $0.464^{* * *}$ \\
\hline Awareness of Brand A CSR behavior (Z) & $0.461^{* * *}$ & 0.051 \\
\hline $\begin{array}{c}\text { Scenario 2: } \\
\text { Brand A purchase experience (D1) b. }\end{array}$ & & $-0.199^{* *}$ \\
\hline $\begin{array}{c}\text { Scenario 3: } \\
\text { Brand B purchase experience (D2) b. }\end{array}$ & & $0.113^{*}$ \\
\hline Z $\times$ D1 & & 0.043 \\
\hline Z $\times$ D2 & $83.203^{* * *}$ & $22.991^{* * *}$ \\
\hline F-Value & 0.212 & 0.274 \\
\hline $\mathrm{R}^{2}$ & - & $0.062^{* * *}$ \\
\hline$\Delta \mathrm{R}^{2}$ & & \multicolumn{2}{|c|}{} \\
\hline
\end{tabular}

a. Demographics -sex, age, level of education, occupation, and monthly allowance-were treated as control variables (not shown).

b. D1, D2: $(0,1)$ dummy variable.

Significance: $* \mathrm{p}<.05 ; * * \mathrm{p}<.01 ; * * \mathrm{p}<.001$

Table 5. Purchase intention for different price increase gap for CSR Brand A across the three scenarios b. c.

\begin{tabular}{|c|c|c|c|c|}
\hline $\begin{array}{c}\text { If the price gap }{ }^{\text {a. }} \\
\text { increased to: }\end{array}$ & $\begin{array}{c}\text { Scenario 1 (N=102) } \\
\text { No prior experience } \\
\text { (Control group) }\end{array}$ & $\begin{array}{c}\text { Scenario 2 (N=99) } \\
\text { Brand A purchase experience } \\
\text { (Frequent buy CSR Brand) }\end{array}$ & $\begin{array}{c}\text { Scenario 3 (N=110) } \\
\text { Brand B purchase experience } \\
\text { (Frequent buy non-CSR Brand) }\end{array}$ & F-value \\
\hline NT\$20 & 5.95 & 6.44 & 5.59 & $8.456^{* * *}$ \\
\hline NT\$25 & 5.44 & 6.17 & 4.90 & $15.116^{* * *}$ \\
\hline NT\$30 & 4.78 & 5.82 & 4.15 & $22.938^{* * *}$ \\
\hline NT\$35 & 3.91 & 5.19 & 3.35 & $24.696^{* * *}$ \\
\hline NT\$40 & 3.32 & 4.81 & 2.97 & $24.673^{* * *}$ \\
\hline
\end{tabular}

a. Initially, the price gap is NT\$15, when CSR Brand A is NT $\$ 174$, and non-CSR Brand B is NT\$159. 1US\$ $=32 \mathrm{NT} \$$.

b. Semantic differential 7-point scale for purchase intention: 7 = Absolutely choosing Brand A; $4=$ no difference; $1=$ Absolutely choosing Brand B.

c. The shadow number in each of the three scenarios: The smallest number larger than the no difference number 4 or around.

Significance: $* * * p<.001$ 


\section{Appendix: The CSR poster}

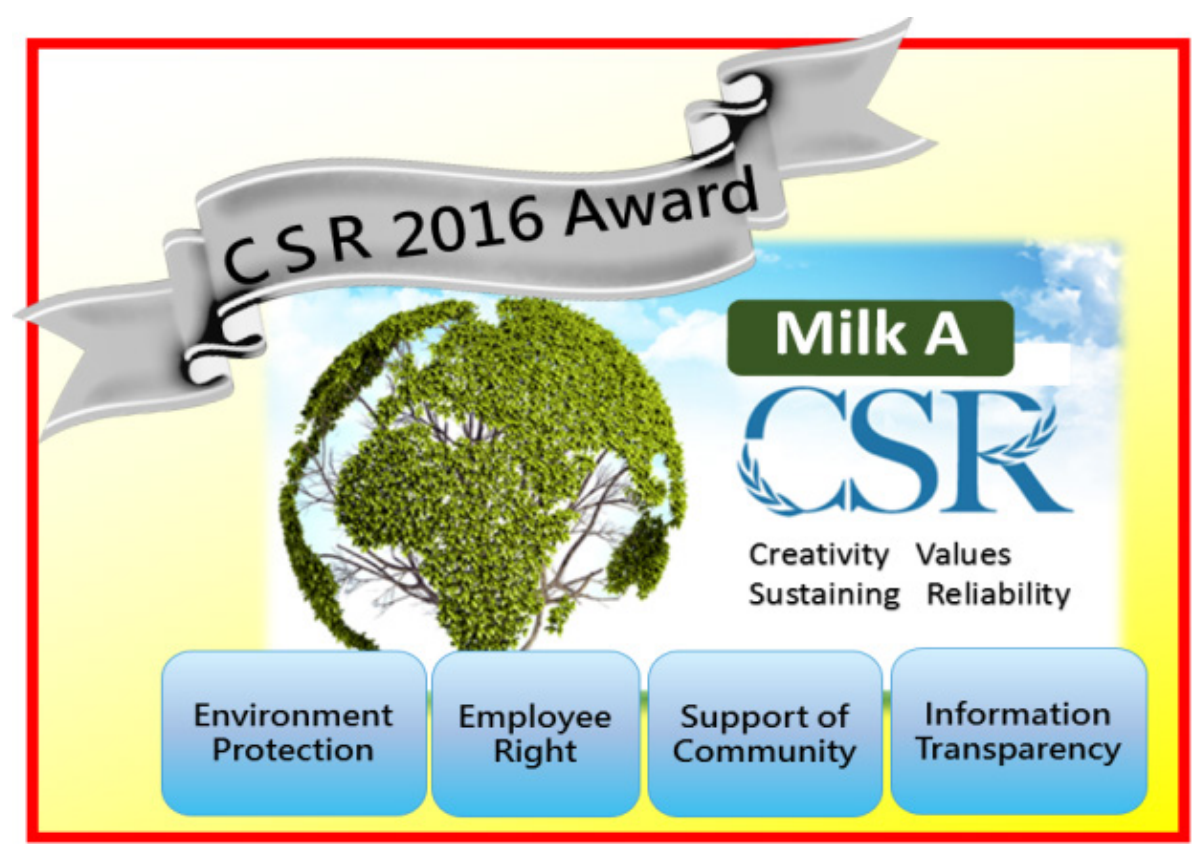

\section{REFERENCES}

[1] K. Gibson. The moral basis of stakeholder theory, Journal of Business Ethics, Vol.26, 245-257, 2000.

[2] S. Hartlieb, B. Jones. Humanising business through ethical labelling: Progress and paradoxes in the UK. Journal of Business Ethics, Vol.88, 583-600, 2009.

[3] D. Jamali, B. Neville. Convergence versus divergence of CSR in developing countries: An embedded multi-layered institutional lens. Journal of Business Ethics, Vol.102, 599-621, 2011.

[4] L. S. Paine. Managing for organizational integrity. Harvard Business Review, Vol.72, No.2, 106-117, 1994.

[5] S.W. Carvalho, S. Sen, M.O. Mota, R.C. Lima. Consumer reactions to CSR: A Brazilian perspective, Journal of Business Ethics, Vol.91, No.2, 291-310, 2010.

[6] N.C. Smith. Changes in Corporate Practices in Response to Public Interest Advocacy and Actions: The Role of Consumer Boycotts and Socially Responsible Corporate Social Responsibility, Working Paper, London Business School, Centre for Marketing, London, 2000.

[7] P.S. Bronn, A.B. Vrioni. Corporate social responsibility and cause-related marketing: an overview, International Journal of Advertising, Vol.20, 207-222, 2001.

[8] P. Auger, T.M. Devinney. Do what consumers say matter? The misalignment of preferences with unconstrained ethical intentions, Journal of Business Ethics, Vol.76, No.4, 361-383, 2003

[9] M.C. Campbell. Perceptions of price unfairness:
Antecedents and consequences, Journal of Marketing Research, Vol.36, No.2, 187-199, 1999a.

[10] M.C. Campbell. Why did you do that? The important role of inferred motive in perceptions of price fairness, Pricing Strategy \& Practice, Vol.8, No.2, 145-152, 1999 b.

[11] M. Strahilevitz. The effects of product type and donation magnitude on willingness to pay more for a charity-linked brand, Journal of Consumer Psychology, Vol.3, No.8, 215-241, 1999.

[12] S. Castaldo, F. Perrini, N. Misani, A. Tencati. The missing link between corporate social responsibility and consumer trust: The case of Fair Trade products. Journal of Business Ethics, Vol.84, No.1, 1-15, 2009.

[13] X. Fang, B.S. Gammoh, K.E. Voss. Building brands through brand alliances: Combining warranty information with a brand ally, Journal of Product \& Brand Management, Vol.22/2, 153-160, 2013.

[14] S. Chatterjee, Y.S. Kand, D.P. MisMarehra. Market signals and relative preference: The moderating effects of conflicting information, decision focus, and need for cognition, Journal of Business Research, Vol.58, 1362-1370, 2005.

[15] R. E. Kihlstrom, M. Riordan. Advertising as a signal, Journal of Political Economics, Vol. 92, June, 427-450, 1984.

[16] K. Bagwell, M. Riordan. High and declining prices signal product quality, The American Economic Review, Vol.81, No.1, 224-239, 1991.

[17] R. Rao, L. Qu, R.W. Ruekert. Signaling unobservable product quality through a brand ally, Journal of Marketing Research, Vol.36, May, 258-268, 1999.

[18] J. Anselmsson, U. Johansson. Corporate social responsibility and the positioning of grocery brands: An exploratory study 
of retailer and manufacturer brands at point of purchase, International Journal of Retail \& Distribution Management, Vol.35, No.10, 835-856, 2007.

[19] J. Klein, N. Dawar. Corporate social responsibility and consumers' attributions and brand evaluations in a product-harm crisis, International Journal of Research in Marketing, Vol.21, No.3, 203-217, 2004.

[20] A. McWilliams, D. Siegel. Corporate social responsibility: A theory of the firm perspective, Academy of Management Review, Vol.26, No.1, 117-127, 2001.

[21] D.S. Siegel, D.F. Vitaliano. An empirical analysis of the strategic use of corporate social responsibility. Journal of Economics \& Management Strategy, Vol.16, No.3, 773-792, 2007.

[22] Z.L. Tian, R. Wang, W. Yang. Consumer responses to corporate social responsibility (CSR) in China", Journal of Business Ethics, Vol.101, No.2, 197-212, 2011.

[23] D. Kong. Does corporate social responsibility matter in the food industry? Evidence from a nature experiment in China. Food Policy, Vol.3, No.37, 323-334, 2012.

[24] L. Chao. More firms tied to tainted formula: China officials say industrial chemical was in baby food. The Wall Street Journal, http://online.wsj.com/article/SB122158011929343485.html, 2008.

[25] P. Kotler, N. Lee. Corporate Social Responsibility: Doing the Most Good for Your Company and Your Cause, New York: John Wiley \& Sons, 2004.

[26] D.R. Lichtenstein, M.E. Drumwright, B.M. Braig. The effect of corporate social responsibility on customer donations to corporate-supported nonprofits, Journal of Marketing, Vol.4, No.68, 16-32, 2004.

[27] D.J. Webb, L.A. Mohr. A typology of consumer responses to cause-related marketing: From skeptics to socially concerned, Journal of Public Policy \& Marketing, Vol. 17, No. 2, 226-238, 1998

[28] P.R. Varadarajan, A. Menon. Cause-related marketing: A co-alignment of marketing strategy and corporate philanthropy, Journal of Marketing, Vol. 52, 58-74, 1988.

[29] M.J. Polonsky and E.K. Macdonald. Exploring the link between cause-related marketing and brand building, International Journal of Nonprofit and Voluntary Sector Marketing, Vol.1, No.5, 46-57, 2000.
[30] M. Berglind, C. Nakata. Cause-related marketing: More buck than bang? Business horizons, Vol. 5, No.48, 443-453, 2005.

[31] R.E. Freeman. Strategic Management: A Stakeholder Approach, Boston: Pitman Publishing, Inc., 1984.

[32] S. Sen, C.B. Bhattacharya. Does doing good always lead to doing better? Consumer reactions to corporate social responsibility. Journal of Marketing Research, Vol.38, No.2, 225-243, 2001

[33] I. Assiouras, O. Ozgen, G. Skourtis. The impact of corporate social response in food industry in product-harm crises, British Food Journal, Vol.1, No.115, 108-123, 2013.

[34] D. Minor, J. Morgan. CSR as reputation insurance. California Management Review, Vol.53, No.3, 40-59, 2011.

[35] C.P. Lin, S.C. Chen, C.K. Chiu, W.Y. Lee. Understanding purchase intention during product-harm crises: Moderating effects of perceived corporate ability and corporate social responsibility, Journal of Business Ethics, Vol.102, No.3, 455-471, 2011.

[36] P. Jones, D. Comfort, D. Hillier. What's in store? Retail marketing and corporate social responsibility. Marketing Intelligence \& Planning, Vol.1, No.25, 17-30, 2007.

[37] P. Jones, D. Comfort, D. Hillier, I. Eastwood. Corporate social responsibility: A case study of the UKs leading food retailers, British Food Journal, Vol.6, No.107, 423-435, 2005.

[38] P. Nelson. Information and consumer behavior. Journal of Political Economy, Vol.78, No.3, 311-329, 1970.

[39] E.H. Creyer. The influence of firm behavior on purchase intention: do consumers really care about business ethics?. Journal of Consumer Marketing, Vol.14, No.6, 421-432, 1997.

[40] Commission of the European Communities. Communication from the Commission to the Council and the European Parliament, December, Brussels, 2006.

[41] L.F. Jamieson, F.M. Bass. Adjusting stated intention measures to predict trial purchase of new products: A comparison of models and methods. Journal of Marketing Research, 336-345, 1989.

[42] Y.H. Hwang. Consumer Response to Marketing Effect of Corporate Social Responsibility - An Experiment, Master Thesis, National Cheng-Kung University, Taiwan, 2015. 